\title{
Liberation psychology: A constructive critical praxis
}

\author{
Psicologia da libertação: uma práxis \\ crítica construtiva
}

\author{
Mark BURTON
}

\begin{abstract}
Can a critical psychology be more than an inward looking critique of the discipline itself? Liberation psychology emerged in Latin America in the 1980s. It is a critical psychology with an action focus, taking sides with the oppressed populations of the continent. The originator of the approach, Ignacio Martín-Baró practiced psychology in the context of the El Salvador an civil war, himself becoming a victim of State repression. The consequences of social conflict have since then been an important theme for liberation psychology. Other areas of emphasis have been community social psychology with an emphasis on the role of social movements and social and political commentary and critique. I will present a review of the field covering some key concepts (conscientisation, de-ideologization, historical memory, reconstruction of psychology from the perspective of the other), its geographical spread (in Latin America and other regions), its organization (the emergence of liberation psychology networks and collectives) and some examples of work that is relevant to social trauma, the theme of this symposium.
\end{abstract}

Uniterms: Dropout; Inclusion; Motivation.

\section{Resumo}

A psicologia crítica pode ser mais do que uma crítica que ol ha para dentro da própria disciplina? A psicologia da libertação surgiu na América Latina na década de 1980. É uma psicologia crítica que tem foco na ação, tomando partido das populações oprimidas do continente. $O$ propositor desta abordagem, Ignacio Martín-Baró, exerceu a psicologia no contexto da guerra civil de El Salvador, sendo ele mesmo uma vítima da opressão do Estado. Desde então, as consequências do conflito social tem sido temas importantes da psicologia da libertação. Outras áreas de foco tem sido a psicologia social Comunitária, com ênfase no papel dos movimentos sociais, e nos comentários e críticas sociais e políticas. Apresentarei uma revisão do campo cobrindo alguns conceitos chaves (conscientização, desideologização, memória histórica, reconstrução da psicologia pela perspectiva do outro), sua abrangência geográfica (na América Latina e em outras regiões), sua organização (a emergência de redes e coletivos da psicologia da libertação) e alguns exemplos de trabalhos relevantes para a compreensão do campo do trauma social, tema deste simpósio.

Unitermos: Desistência; Inclusão; Motivação.

I am very honoured to be here in Diyarbakir at this symposium on critical psychology and social trauma and I do hope that I can contribute something useful for the struggles here.

rur

1 Manchester Metropolitan University. Manchester, United Kingdom. E-mail: <mark.burton@poptel.org>.

Extenced version of keynote talk given at the Third Critical Psychology Symposium, Diyarbakir, Turkey, 15-16 September, 2012. I am grateful to colleagues from TODAP for the invitation. 
I am going to talk about a Latin American critical psychology. Why might that be relevant? I am struck by the parallels. A middle income country on the periphery of the capitalist centre. A neoliberal regime. A history of military dictatorship. Repression on an 'industrial scale' with torture, imprisonment and extrajudicial killings. Persecution and exclusion of minorities. Social trauma. And a mainstream psychology that serves the system. Where am I? Honduras? Guatemala? Argentina? Honduras? Colombia? Chile?

It may seem strange for an Englishman to be representing the Latin American work and indeed it is. There are better authorities on the subject but distance and language means you have me. However, I am also clear that the approach is not unique to Latin America. There are parallel developments in several other places, some of which go under the name of liberation psychology and others which don't.

There are various critical psychologies and they differ. You now have a translation of a North American approach (Fox, Prilleltensky \& Austin, 2009; 2012). There is a very interesting South African version (Hook, Kiguwa \& Mkhize, 2004), there is a European approach, generally far too theoretical and abstract for me: too isolated from political praxis, too discursive, too postmodern. So let's first consider what critical psychology is meant to achieve.

\section{Is critical psychology just another academic discipline? ${ }^{2}$}

Critical psychology attempts to correct the errors of dominant psychology, but the ways different critical psychologies have understood and attempted that task have differed greatly between different workers and different places.

Critical psychology arose in large part from what has been called the crisis in social psychology dating from the late 1960s well into the 1970s. Dominant, English-speaking (and especially North American), largely experimental, social psychology was criticised as being largely irrelevant to real human needs and contexts, and because it wrongly assumed that its methods enabled the discovery of fundamental principles, processes and even laws of human behaviour, that could be generalised to all situations. To this critique, largely from within social psychology, were added related concerns, for example about the abuses of psychology and of the medicalisation of distress in the mental health system (Anonymous,1970s nd.).

But from that point a number of paths were followed (Armistead, 1974; Parker, 1989; 1999). Some emphasised the dramaturgical metaphor for understanding human action (Harré \& Secord, 1972), others emphasised the study of experience using phenomenological concepts and methods. Some assimilated Marxist and Marxian thinking (Ingleby, 1970; Parker \& Spears, 1996) and others emphasised social commitment and action. Others still focussed on the oppressive roles and uses of psychological concepts and knowledge (Ingleby, 1985; Rose, 1985) while others focussed on the development of new methods (Reason \& Rowan, 1981).

By the 1980s, it was possible to identify some dominant trends. In Europe (predominantly) the 'discursive turn', in the context of a post-structuralist and post-modernist movement away from the structuralism and Marxism of previous generations, was particularly influential. An early statement of this approach was the opening article of the short - lived journal Ideology and Consciousness (Adlam et al., 1977; Potter \& Wetherall, 1987). Just as the pretensions of empiricism in revealing general principles and theories had been rejected, so now were the so called grand theories of social systems. Instead there emerged a highly parochial focus on the particularities of social situations and above all of the use of language. In some variants all psychological and social phenomena were reduced to texts (and the term reduced is used here consciously to suggest that this was not unlike the reductionism so criticised in previous psychologies). In some variants the relativism of postmodernism meant a rejection of ethical judgements and also it seemed of methodological standards - say what you like seemed to be the norm. At its worst this meant an individualistic

2502 This section of the paper was not presented at the symposium due to lack of time. 
rendering of critical rather than critical as the questioning of a body of theory and practice by reference to another, sharper and more penetrating theoretical framework (such as the analysis of class or patriarchal relations). Indeed the great value accorded to personal experience and the emphasis on the construction of reality through the use of language now seems like a retreat from a really social understanding of people in society since it involves a new dualism - that between an unknowable social reality and the social psychology of language. Concepts of social construction and cognitive representation seem to maintain the bourgeois distinction between individual and society, or at best they fail to theorise the processes by which concrete individuals (Sève, 1978) are formed in contexts of social reproduction, socialisation and social transformation (Bhaskar, 1979).

It would be unfair to suggest that the discursive and poststructuralist turn brought no advances in understanding: to name but three, there was Silverman's use of discursive analysis to show how social discrimination in the medical consulting room reduced the life expectancy of children with Down syndrome (Silverman, 1981), or Figlio's use of a Foucauldian framework to explore what he called the social constitution (at once the causation and the ideological construction) of chronic disease (Figlio, 1978), and finally Rose's analysis of the development of the 'psy complex' through the involvement of psychological testing in the segregative and eugenic social policies on disability in early C20 Britain (Rose, 1985).

However, in my view, such innovations were few and European critical psychology came to be characterised by a hyper-development of ungrounded theory, typically impenetrable to the outsider, with little apparent applicability to the harshening social reality outside the academy. This tendency I call academic in the ivory tower sense of the word: the problem is not the development of theory but the alienation of theory from social causes, experience and struggles. There is not sufficient time to explore the reasons for critical psychology taking this path in Europe, but it would appear to do with the privileged position of academic psychologists in the context of the retreat of progressive ideas in the period from the mid 1970s under the neoliberal onslaught.

\section{A Latin American alternative}

In Latin America, another path was being followed - not exclusively since the post-modern virus was contagious (Lacerda, 2010) - but by enough people to demonstrate that another critical psychology was possible. Here the tradition of praxis in fields such as theology and philosophy of liberation, the Theatre of the Oppressed and in Popular Pedagogy, as well as in some of the region's social movements, provided an alternative and more socially engaged model (Chart 1) shows some of the principal currents). In the two originally separate but now linked areas of community social psychology and psychology of liberation, the preferential option for the oppressed majorities was taken, constructing critical psychologies that dealt with social reality, as reality and not as some linguistic chimera. That reality had to be clarified and in the words

\section{Chart 1}

Latin American Praxis: Some key currents

\begin{tabular}{ll}
\hline Framework & Countries of origin and major development. \\
\hline Critical/militant sociology participatory action research & Colombia. \\
Theology of liberation & Argentina, El Salvador, Brazil, Peru. \\
Philosophy of liberation & Argentina, Mexico. \\
Popular pedagogy & Brazil, Chile, Guinea, Bissau, United States. \\
Community social psychology & Venezuela, Puerto Rico, Brazil, Mexico Colombia, El Salvador, Panama, \\
& Peru, Dominican Republic, and others. \\
Psychology of liberation & El Salvador, Venezuela, Mexico, Guatemala, Costa Rica and others. \\
Community therapy & Brazil. \\
Organisation workshop & Brazil, Honduras, Nicaragua. \\
Theatre of the Oppressed/Forum Theatre & Brazil. \\
Revolutionary Psychology/Cultural historical approach & (Soviet Union), Cuba. \\
\hline
\end{tabular}


of Ignacio Martín-Baró de-ideologised so it could be seen for what it was, in order that it could be changed (Martín-Baró, 1996a).

Latin America has had its share of post-modern and hyper-theoretical critical psychology and indeed this is perhaps no more than another manifestation of an inferiority complex that leads to the imitation of work from the core countries (de la Torre, 1995). However, other developments can be identified (Gonzalez Rey, in press), pointing to a socially committed psychology characterised by the reconstruction of psychology in dynamic relationship with social issues, social action and social movements. This was exactly the approach taken by Martín-Baró in his programmatic articles and his texts of social psychology (Burton, 2004a; 2004b; Burton \& Kagan, 2005; Martín-Baró, 1983; 1986; 1989a; 1996b; 1998). It also characterises the best of Latin American community psychology (Góis, 2005; Montero, 1996; Montero \& Serrano García, 2011; Ximenes, Amaral, \& Rebouças, 2008) and related work within the framework of liberation psychology (Barrero \& Salas, 2010; Dobles \& Baltodano, 2010; Dobles, Baltodano, \& Leandro, 2007; Guzzo \& Lacerda, 2011).

\section{Martín-Baró's proposal and his approach}

So what is the psychology of liberation? It should be noted that it has several roots in addition to the critique of Anglo-American psychology, it draws fairly eclectically on the wider Latin American critical tradition, the theology and philosophy of liberation (Martín-Baró was one of a group of radical Roman Catholic priests at the University of Central America, 5 of whom were murdered with him) and the experience of the Brazilian Christian Base Communities, Marxism and the work of earlier critical psychologists from the South and its diaspora (Fanon in particular), and later workers have also made use of radical currents in psychoanalysis, soviet and Cuban cultural-historical psychology and phenomenological approaches in psychology.

It is worth quoting from its originator, MartínBaró (Martín-Baró, 1996b) at some length to illustrate this approach:
1) Latin American psychology must switch focus from itself, stop being preoccupied with its scientific and social status and self- define as an effective service for the needs of the numerous majority... which should constitute the primary object of its work... (p.26).

2) The objective of serving the need for liberation ... requires a new form of seeking knowledge: the truth of the Latin American people is not to be found in its oppressed present, but in its tomorrow of freedom; the truth of the numerous majority is not to be found but to be made... . The new perspective has to be from below, from the numerous oppressed majority... . Assuming a new perspective does not suppose, obviously, throwing out all of our knowledge; what it does suppose is its being made relative and critically revised from the perspective of the numerous majority. Only from there will the theories and models demonstrate their validity or deficiency, their usefulness or uselessness, their universality or provincialism: only from there will the techniques that have been learned demonstrate their potential for liberation or subjugation... (p.27).

3) All human knowledge is conditioned by the limits imposed by reality itself. In many respects reality is opaque, and only by acting upon it, only by transforming it, is it possible for the human being to gain knowledge of it. What we see and how we see it is certainly conditioned by our perspective, by the place from which we look at history; but it is conditioned also by reality itself. So to acquire new psychological knowledge it is not enough that we base ourselves in the perspective of the people; it is necessary to involve ourselves in a new praxis, an activity that transforms reality, allowing us to know it not just in what it is but in what it is not, so thereby we can try to shift it towards what it should $b^{3}$ (p.28).

I can illustrate the approach by referring to the work of community psychologists from the Universidade Federal do Ceará, Brazil (Góis, 2005; Ximenes et al., 2008) texts cited above are examples of their output which has a history of some 30 years. Here psychologists work within the context of community social movements, under their leadership, contributing their expertise and contributing to the production of new knowledge for social action. Here for example a radically different

2523 The translation is my own, departing in places from the Harvard version. 
approach to intervention with mental distress can be witnessed, it was not designed by psychologists but emerged from the practice of community based social movements, drawing on but transcending the community therapy movement so that people are integrated in social groups and participate in social action, finding new roles capacities and meaning.

\section{Key ideas}

I am now going to discuss three key ideas in liberation psychology since these demonstrate its distinctiveness. But note that liberation psychology is richer than this selection suggests. The Attachement indicates some other dimensions. See also <http:// libpsy.org/sources-on-liberation-psychology $>$ for English language sources on liberation psychology.

\section{Conscientisation}

In Latin America, a notion of liberatory human development has arisen with diverse roots, across a series of disciplines and social movements. A key idea is that liberation is not something that can be given, nor is it a discrete event but rather it is a movement and a series of processes. It often has origins in the interaction of two types of agents or activists: external 'catalytic' agents (which could include psychologists) and the oppressed groups themselves.

Freire's concept of conscientisation (Freire, 1972) is a much-cited formulation of this. Martín-Baró (1986, 1996c) regarded conscientisation as a key concept, explaining it as a person or people being transformed through changing their reality, through an active process of dialogue in which there is a gradual decoding of their world, as the mechanisms of oppression and dehumanisation are grasped. This in turn opens up new possibilities for action. The new knowledge of the surrounding reality leads to new self-understanding about the roots of what people are and what they can become. Anyone who has worked in a facilitative way with oppressed groups for any time will be familiar with this energizing processes that can often seem like an awakening.

\section{De-ideologization}

Social reality can be difficult to see for what it is, not just for the people, but for the theory and practice of psychology itself. It is therefore necessary to deideologise reality, to peel off the layers of ideology that individualise and naturalise social phenomena. MartínBaró did this in relation to the problem of conformist fatalism in Latin American societies and the myth of the 'lazy Latino' (Martín-Baró, 1987; 1996d). He also used opinion surveys to counter the propaganda of the Salvadorian government about the opinions of the population (Martín-Baró, 1989b; 1996a), which he both fed back to them (Soto, 2010) and also made available to an international audience, an important contribution to undermining the support given by the United States to the military and a reason for his murder by the forces of the State (Bernabeu \& Blum, 2012).

\section{Historical memory}

A further tool in the de-ideologisation of social reality, especially important in Latin America is the recovery of historical memory. Martín-Baró pointed out that it is difficult to meet basic everyday needs when the majority live in the psychological present, in a here and now that ignores both past and future. The dominant ideology structures a reality that is apparently natural and a historical, leading to its acceptance without further questioning. This makes it difficult to draw lessons from experience and, what Martín-Baró considered most important, to discover the roots of their own identity, as much to interpret its current meaning as to surface alternative conceptions of what it might become - again combating fatalism and becoming social actors.

It seems likely that the particular importance of recovering historical memory owes something to the specific context of El Salvador. A genocide took place in the 1920s: he communist revolutionary Farubundo Martí had led a socialist insurrection, supported by many of the indigenous peasants. It was suppressed, with Martí being murdered and the killing of some 50,000 people, including whole villages, especially in Western El Salvador (Chávez, 2012; Equipo Maíz, 2007). It was enough to have indigenous features. As a result people gave up their culture (dress, customs and the Nahuat language) in order to survive. There are always severe psychological and social consequences of such deculturation and in El Salvador this has led to the 
depreciation of the Salvadorian, so that for example although there is Salvadorian football the public follows European teams.

So Martín-Baró (1986; 1996c) recommended recovering selectively and collectively elements from the past that were effective for defending the interests of the exploited classes and that could in their turn again be helpful for a conscious struggle for a better world, regaining pride of belonging to a people and gaining a sense of identity with a tradition and a culture.

\section{Reconstruction of psychology from the perspective of the 'other'}

\begin{abstract}
As Ignacio Dobles has pointed out:
It is interesting that in this process of revision and redefinition, [Martín-Baró] didn't adopt a hypercritical stance that devalued the whole legacy of experience and knowledge up to the present... but what he did instead was... . To examine the existing body of work from another perspective, in this case a reading from the point of view of the aspirations and the needs of the popular Latin American majorities. The proposal is not provincial, nor is it limited by absurd regionalism: it is a social psychology from Central America, not a social psychology of Central America (Dobles, 2009a, p.2).
\end{abstract}

This idea, of a constructive but rigorous critique from the perspective of the oppressed other is central to the models of Latin American critical praxis in a variety of fields, what the philosopher Enrique Dussel calls the analectic method (Burton, 2011; Burton \& Flores, 2011; Dussel, 1985; 1997; Flores, 2009).

\section{Liberation psychology as a movement}

Since the death of Martín-Baró, and especially from the end of the 1990s, there has been the development of a movement for the psychology of liberation in Latin America. There have been international congresses in a variety of countries; there are established liberation psychology collectives in Colombia and Costa Rica and a developing one in El Salvador as well as other less formal groupings elsewhere. There is a email list with (in September, 2012) 948 members. In 2011 an English language liberation psychology network was established with an online presence at <http:// libpsy.org/>. It aims to support liberation psychology inspired work going on in countries, North and South, where English is a medium of communication. It also seeks to act as a bridge with the Spanish and Portuguese speaking networks.

A considerable amount of work has been conducted under the umbrella of these networks and movements although the psychology of liberation remains a minority field. Psychologists with a liberatory orientation work in a variety of fields, principally in community social psychology, in relation to social trauma resulting from conflict and oppression, and on the social psychological critique of policy and ideology. At its best liberation psychology brings new insights and perspectives to social movements although at times the networks seem to act as little more than channels for communicating news about various sites of political repression and struggle.

\section{Liberation psychology and social trauma: Memory and collective action}

Martín-Baró's approach developed in the context of armed conflict and repression. Such events have characterized the political and social situation in much of Latin America, with particular intensity during the period of the military dictatorships from the date of the military coup in Brazil in 1964 up until the Central American peace accords-ElSalvador in 1992; Guatemala in 1996; Nicaragua in 1987 and the restoration of parliamentary democracy in other countries from the mid 1980s. In many countries there had been the suspension of civil rights, the imprisonment of political activists, the use of torture, disappearances and murders of activists. In some countries there was civil war between popular revolutionary movements and the forces of the State. In others there were more marginal insurgencies. In some countries (Colombia, Honduras) disappearances still occur, with peasant and trade union activists and journalists particularly targeted by State agencies or groups working for oligarchic interests. Much of the conflict has been tied to United States intervention, for example the installation of the Pinochet junta in Chile, the funding of the military and the deployment of advisors on counter-insurgency and 
psychological warfare, collusion with the the removal of elected governments (Haiti, Honduras, Paraguay in the last 7 years), and invasions and interventions in a majority of countries over the last 150 years. Within this context there have been genocidal actions and population clearances and movements of refugees.

With this history, the consequences of social trauma have been a major concern for liberation psychology. Specific foci have been:

1) Work with the victims of torture (Agger \& Buus Jensen, 1996; Castaño \& López, 1994; Hollander, 1997; Lira, 1994; Lira \& Castillo, 1991; Lira \& Weinstein, 2000);

2) Work with families of the disappeared or murdered (Girón, 2007);

3) Work with displaced populations and accompaniment of people in 'limit situations' (Tovar, 2007);

4) Campaigns for the acknowledgement of crimes, reparations and against impunity (Barrero \& Salas, 2010; Girón, 2007; Portillo, Gaborit, \& Cruz, 2005);

5) Analysis of the peace processes (Dobles, 2009b);

6) Research on the consequences of a culture of violence (Estrada, Ibarra \& Sarmiento, 2007; Molina, 2005).

Rather than look at each of these areas I will review some common issues and principles that have emerged. They are:

1) The importance of memory and commemoration;

2) Moving from an individual perspective to a collective one;

3) The struggle against impunity.

\section{The importance of memory and commemoration}

The importance of historical memory was discussed above as one of the key ideas for liberation psychology. Consistently with this psychologists with a liberatory orientation have worked on the importance of ensuring that events involving violence against individuals, groups and communities is not forgotten.

This is in a context where official policy often recommends forgiveness and forgetting. Collective acts of commemoration are a particular aspect of this work which take a variety of forms including the production and sharing of testimonies, artistic activity and the exhumation and reburial of victims of genocidal acts - especially important in Guatemala where 20,000 people, largely indigenous, were killed, mostly by the army (Comissíon para el Esclarecimiento Histórico, 1999).

Gaborit (2007) identifies four functions of commemoration:

- Firstly, it offers dignity to the feelings of those affected. This is important in a context where the official history has treated such personal or collective feelings as suspect, so that their airing is often surreptitions or clandestine and the feelings themselves become infused with guilt and shame.

- Secondly, commemoration makes the feelings of the affected public and objective rather than something merely personal, private or subjective. Understanding their experience in this socially validated way helps the affected to understand how it impacts on their present social relations and hence on their own identity and well-being. Moreover, this legitimation of personal experience assists in the construction of possible means of promoting reconciliation and repairing the social fabric. As Martín-Baró noted (quoted without citation in Girón (2010), while repression eliminates its target people, it also has the wider effect of terrorizing all those who identify with them. The recovery of memory is the beginning of the process of reversing that dynamic.

- Thirdly, whilst intensifying feelings of pain and injustice, collective commemoration facilitates solidarity and social mobilization. Evidence from the Guatemalan exhumations cited by Gaborit indicates that while participation does not protect people from pain and fear it does reduce social isolation, bringing about intense feelings of belonging and union, not just with the present community but with those that went before.

- Finally, Gaboritsuggests that the commemorations also dignify the lives of those who did not survive institutionalized violence, and in many cases this makes it clear to all that there were indeed victims, something that has been repeatedly denied by those responsible for the repression. 


\section{Moving from an individual perspective to a collective one}

The work on recovering memory and commemorating atrocities then involves bringing memory from the private sphere to the public one, from individualized distress to collective experience. A similar direction of travel takes place in work - with victims of torture. An outstanding example of this is found in the work of Instituto Latinoamericano de Salud Mental y Derechos Humanos (ILAS, Latin American Institute of Mental Health and Human Rights), working on the mental health of people affected by violations of human rights during the military regime in Chile, 1973-1990 (ILAS, 2003). ILAS has helped in other situations of political violence, both nationally and internationally, for example in Angola (Agger \& Buus Jensen, 1996; ILAS, 2003). Their model was used in Bosnia and has a relevance to people arriving in more peaceful countries as refugees from torture or other trauma. In the United Kingdom (UK), for example, there has also been recent interest in combining frameworks from liberation psychology with therapeutic methods such as narrative therapy (Afuape, 2011).

In the work of ILAS and other teams, there is emphasis on making the suffering a social, shared, thing, rather than a secret, internalized distress, and on again taking up active social roles, of recovering an existential life-project (Lira, 2001; Lira \&Weinstein, 2000). The theme of recovering memories, of what happened, and of those who have been taken away, is common to this and similar work (Hollander, 1997). This emphasis is important in terms of the general emphasis in liberatory praxis on the role of collective memory as a political and social resource, but also because of the officially sanctioned denial of what happened.

Perspectives of this kind have also helped liberation psychologists develop a critique of dominant conceptions of trauma. For example Portillo notes that the standard account of Post traumatic Stress Disorder does not recognize the intergenerational impact of such stress (Portillo, 2005). The 'really social' perspective is shared by other workers with a liberatory perspective in Latin America; for example the community psychology that has developed in Ceará, North East Brazil, mentioned earlier, integrates community therapy as part of a process, led by community based social movements for individual and social change and promotion of community health and well-being (Góis, 2005; Ximenes et al., 2008).

\section{The struggle against impunity}

The problem of impunity for perpetrators of organized violence is endemic in Latin America. The work of ILAS was important in raising this issue in Chile feeding into the prosecution of perpetrators (Lira, 2000) and the struggle against impunity and there has been work in several locations on the problem.

Again historical memory, testimony and collective action are important in overcoming the externally and self-imposed silence of the victims. This work on a wider scale than attending to personal distress also reflects another emphasis in liberation psychology, the importance of changing society itself and the legitimate role of psychologists in this. The work of liberation psychologists in the struggle against impunity is typically highly engaged with other disciplines and sectors, including social movement organizations, faith organizations, forensic archeologists, health workers, lawyers, political representatives and community leaders, as well as international partners.

This last point leads to my conclusion. Liberation is not something that psychologists can achieve alone, it is essential to work in alliance, as part of broader progressive social movements. Liberation psychology follows Martín-Baró's call to face outwards, focusing not on the problems of the discipline but on the problems of society. In this it is a powerful corrective to the isolation of much critical psychology which at times appears to do just the opposite of what Martín-Baró proposed.

\section{Referências}

Adlam, D., Henriques, J., Rose, N., Salfield, A., Venn, C., \& Walkerdine, V. (1977). Psychology, ideology and the human subject. Ideology \& Consciousness, 1, 5-56.

Afuape, T. (2011). Power, resistance and liberation in therapy with survivors of trauma. London: Routledge.

Agger, I., \& Buus Jensen, S. (1996). Trauma and healing under state terrorism. London: Zed.

Anonymous (1970s n.d). Rat, myth and magic: A political critique of psychology. 
Armistead, N. (1974). Reconstructing social psychology. Harmondsworth: Penguin.

Barrero, E., \& Salas, J. R. J. (2010). Memoria, silencio y acción psicosocial: reflexiones sobre por qué recordar en Colombia. Bogotá: Cátedra Libre Matín-Baró

Bernabeu, A., \& Blum, C. P. (2012). The road to Spain: The Jesuit massacre and the struggle against impunity in $\mathrm{El}$ Salvador. Peace and Conflict: Journal of Peace Psychology, 18(1), 96-100.

Bhaskar, R. (1979). On the possibility of social scientific knowledge and the limits of naturalism. In J. Mepham \& D. H. Ruben (Eds.), Issues in Marxist philosophy: Epistemology, science, ideology (Vol. 3, pp.107-139). Brighton: Harvester.

Burton, M. (2004a). Radical Psychology networks: A review and guide. Journal of Community \& Applied Social Psychology, 14(2), 119-130.

Burton, M. (2004b). Viva nacho!: Liberating psychology in Latin America. The Psychologist, 17(10), 584-587.

Burton, M. (2011). A second psychology of liberation?: Valuing and moving beyond the Latin American. Retrieved from <http://libpsy.org/wp-content/uploads/2011/11/Asecond-psychology-of-liberation.pdf>.

Burton, M., \& Flores, J. M. (2011). Introducing Dussel: The philosophy of liberation and a really social psychology. Psychology in Society, 41, 20-39.

Burton, M., \& Kagan, C. (2005). Liberation social psychology: Learning from Latin America. Journal of Community and Applied Social Psychology, 15(1), 63-78.

Castaño, B. L., \& López, P. (1994). Chapter 2. In E. Lira (Ed.), Psicología y violencia política en América Latina (pp.37-69). Santiago de Chile: ILAS.

Comissíon para el Esclarecimiento Histórico. (1999). Guatemala: memory of silence. Conclusions and recommendations of the report of the commission for historical clarification. Retrieved from $<\mathrm{http}$ ://shr.aaas.org/ guatemala/ceh/inEnglishandSpanish>.

Chávez, J. M. (2012). The university for social change and the legacy of Ignacio Martín-Baró, S. J. Peace and Conflict: Journal of Peace Psychology, 18(1), 68-76.

Dobles, I. (2009a). Ignacio Martín Baró y psicología de la liberación: un desafío vigente. Disponible <http:// www.catedralibremartinbaro.org/pdfs/PCL_DoblesI_ UnDesaf_ioVigente.pdf>

Dobles, I. (2009b). Memorias del dolor: consideraciones acerca de las comisiones de la verdad en América Latina. San José, Costa Rica: Arlekín.

Dobles, I., \& Baltodano, S. (2010). Psicología: dominación, compromiso y transformación social. San José: Editorial Universidad de Costa Rica.

Dobles, I., Baltodano, S., \& Leandro, V. (2007). Psicología de la liberación en el contexto de la globalización neoliberal: acciones, reflexiones y desafíos. San José: Editorial Universidad de Costa Rica.

Dussel, E. (1985). Philosophy of liberation. New York: Orbis Books.
Dussel, E. (1997). The architectonic of the ethics of liberation. In D. Batstone, E. Mendieta, L. A. Lorentzen \& D. N. Hopkins (Eds.), Liberation theologies, postmodernity, and the Americas. London: Routledge.

Equipo Maíz, C. A. (2007). Vida de Farabundo Martí: 18931932. El Salvador: Asociación Equipo Maíz.

Estrada, A. M., Ibarra, C., \& Sarmiento, E. (2007). Regulation and control of subjectivity and private life in the context of armed conflict in Colombia. Community, Work \& Family, 10(3), 257-281.

Figlio, K. (1978). Chlororis and chronic disease in 19th-century Britain: The social constitution of somatic illness in a capitalist society. International Journal of Health Services, 8 , 589-617.

Flores, J. M. (2009). Praxis and liberation in the context of Latin American theory. In M. Montero \& C. Sonn (Eds.), Psychology of liberation: Theory and applications (pp.1-26). New York: Springer.

Fox, D., Prilleltensky, I., \& Austin, S. (2009). Critical psychology: An introduction. Los Angeles: SAGE.

Fox, D., Prilleltensky, I., \& Austin, S. (Eds.). (2012). Eleștirel psikoloji. Istanbul: [Ayrinti].

Freire, P. (1972). Pedagogy of the oppressed. Harmondsworth: Penguin.

Gaborit, M. (2007). Memoria histórica: aspectos psicosociales en la recuperación de la memoria histórica. In I. Dobles, S. Baltodano \& V. Leandro (Eds.), Psicología de la liberación en el contexto de la globalización neoliberal: acciones, reflexiones y desafíos. San José: Editorial Universidad de Costa Rica.

Girón, C. (2007). La galería de la memoria: una experiencia de trabajo en Colombia con víctimas de la violencia sociopolítica en medio del conflicto armado y la polarización social. In I. Dobles, S. Baltodano \& V. Leandro (Eds.), Psicología de la liberación en el contexto de la globalización neoliberal:acciones, reflexiones y desafíos. San José: Editorial Universidad de Costa Rica.

Girón, C. (2010). El rol reparador y transformador de la memoria: de la eficacia simbólica a la acción política colectiva. In E. Barrero \& J. R. Salas (Eds.), Memoria, silencio y acción psicosocial. Bogotá: Cátedra Libre Matín-Baró.

Góis, C. W. L. (2005). Psicologia comunitária: actividade e consciência. Fortaleza: Publicações Instituto Paulo Freire de Estudos Psicossociais.

Gonzalez Rey, F. (in press). Paths, development and discontinuity of some critical approaches to psychology in Latin America: What happened in that history? Annual Review of Critical Psychology.

Guzzo, R. S. L., \& Lacerda, F. (2011). Psicologia social para América Latina: o resgate da psicologia e libertação. Campinas: Alínea.

Harré, R., \& Secord, P. F. (1972). The explanation of social behaviour. Oxford: Blackwell.

Hollander, N. C. (1997). Love in a time of hate: Liberation psychology in Latin America. New Jersey: Rutgers University Press. 
Hook, D., Kiguwa, P., \& Mkhize, N. (2004). Introduction to critical psychology. Lansdowne: UCT Press.

Instituto Latinoamericano de Salud Mental e Derechos Humanos. Qué is ILAS. (2003). São Paulo: Autor. Disponible en septiembre 6, 2012, disponible <http://www.ilas.cl/ presenta.htm>.

Ingleby, D. (1970). Ideology and the human sciences: Some comments on the role of reification in Psychology and psychiatry. Human Context, 2, 159-187.

Ingleby, D. (1985). Professionals as socializers: The 'psy complex'. Research in Law, Deviance and Social Control, 7, 79-109.

Lacerda, F. (2010). Notas sobre o desenvolvimento da psicologia social comunitária. In F. Lacerda \& R. S. L. Guzzo (Eds.), Psicologia e sociedade: interfaces no debate sobre a questão social (pt.1, cap. 2). Campinas: Alínea.

Lira, E. (1994). Psicología y violencia política en América Latina. Santiago de Chile: Ediciones CESO.

Lira, E. (2000). Verdad, justicia e impunidad: memoria, perdón y olvido. In J. J. Vázquez (Ed.), Psicología social y liberación en América Latina (pp.133-153). Mexico City: Universidad Autónoma Metropolitana.

Lira, E. (2001). Violence, fear, and impunity: Reflections on subjective and political obstacles for peace. Peace and Conflict: Journal of Peace Psychology, 7(2):109-118.

Lira, E., \& Castillo, M. I. (1991). Psicología de la amenaza política y el miedo. Santiago: ILAS.

Lira, E., \& Weinstein, E. (2000). La tortura: conceptualización psicológica y proceso terapéutico. In I. Martín-Baró (Ed.), Psicología social de la guerra. San Salvador: UCA Editores.

Martín-Baró, I. (1983). Acción eldeología: psicología social desde Centroamérica I. San Salvador: UCA Editores.

Martín-Baró, I. (1986). Hacia una psicología de la liberación. Boletin de Psicología, 22, 219-231. Recuperado en septiembre 23, 2011, disponible <http://www.uca. edu.sv/deptos/psicolog/hacia.htm>.

Martín-Baró, I. (1987). El latino indolente: carácter ideológico del fatalismo latinoamericano. In M. Montero (Ed.), Psicología politica latinoamericana (pp.135-162). Caracas: Panapo.

Martín-Baró, I. (1989a). Sistema, grupo y poder: psicología social desde centroamérica II. San Salvador: UCA Editores.

Martín-Baró, I. (1989b). La opinión pública salvadoreña (1987-1988). San Salvador: UCA Editores.

Martín-Baró, I. (1996a). Public opinion research as a de-ideologizing instrument. In A. Aron \& S. Corne (Eds.), Readings for a liberation psychology. New York: Harvard University Press.

Martín-Baró, I. (1996b). Writings for a liberation psychology. New York: Harvard University Press.

Martín-Baró, I. (1996c). Toward a liberation psychology. In A. Aron \& S. Corne (Eds.), Writings for a liberation psychology. New York: Harvard University Press.

Martín-Baró, I. (1996d). The lazy latino: The ideological 258 nature of Latin American fatalism. In A. Aron \& S. Corne
(Eds.), Writings for a liberation psychology (pp.198-220). Cambridge Harvard University Press.

Martín-Baró, I. (1998). Retos y perspectivas de la psicología latinoamericana. In A. Blanco (Ed.), Psicología de la liberación. Madrid: Trotta.

Molina, N. (2005). Resistencia comunitaria y transformación de conflictos. Reflexión Política, 7(14), 70-82.

Montero, M. (1996). Parallel lives: Community psychology in Latin America and the United States. American Journal of Community Psychology, 24(5), 589-606.

Montero, M., \& Serrano García, I. (2011). Historias de la psicología en América Latina: participación y transformación. Buenos Aires: Paidós.

Parker, I. (1989). The crisis in modern social psychology: And how to end it. London: Routledge.

Parker, I. (1999). Critical psychology: Critical links. Annual Review of Critical Psychology, 1(1), 3-18.

Parker, I., \& Spears, R. (1996). Psychology and society. London: Pluto Press.

Portillo, N. (2005). Juventud y trauma psicosocial en El Salvador. In N. Portillo, M. Gaborit \& J. M. Cruz (Eds.), Psicología socialen la posguerra:teoríay aplicaciones desdeEl Salvador (pp.249-289). San Salvador: UCA Editores.

Portillo, N., Gaborit, M., \& Cruz, J. M. (Eds.). (2005). Psicología socialen la posguerra:teoría y aplicaciones desde EI Salvador. San Salvador: UCA Editors.

Potter, J., \& Wetherall, M. (1987). Discourse and social psychology: Beyond attitudes and behaviour. London: Sage.

Reason, P., \& Rowan, J. (1981). Human inquiry: A sourcebook of new paradigm research. Chichester: Wiley.

Rose, N. (1985). The psychological complex: Society, politics and society in england, 1869-1939. London: Routledge.

Sève, L. (1978). Man in marxist theory and the psychology of personality. Sussex: Harvester Press.

Silverman, D. (1981). The child as social object: Sociology of health and illness. Socialogy of Health \& IIIness, 3, 354-274.

Soto, R. (2010). Martín-Baró y el uso de la encuesta como instrumento concientizador. Revista Salvadoreña de Psicología, 1(1), 83-91.

de la Torre, C. (1995). Psicología latinoamericana: entre la dependencia y la identidad. Havana: Editorial Felix Varela.

Tovar, C. (2007). Acompañamiento psicosocial a personas en situaciones de desplazamiento. In I. Dobles, S. Baltodano \&V. Leandro (Eds.), Ciudad Universitaria Rodrigo Facio. San José: Editorial Universidad de Costa Rica.

Ximenes, V. M., Amaral, C. E. M., \& Rebouças, F. G. (2008). Psicologia comunitária e educação popular: vivências de extensão/Cooperação Universitária no Ceará. Fortaleza: Universidade Federal do Ceará.

Received on: 14/12/2012

Approved on: 31/1/2013 


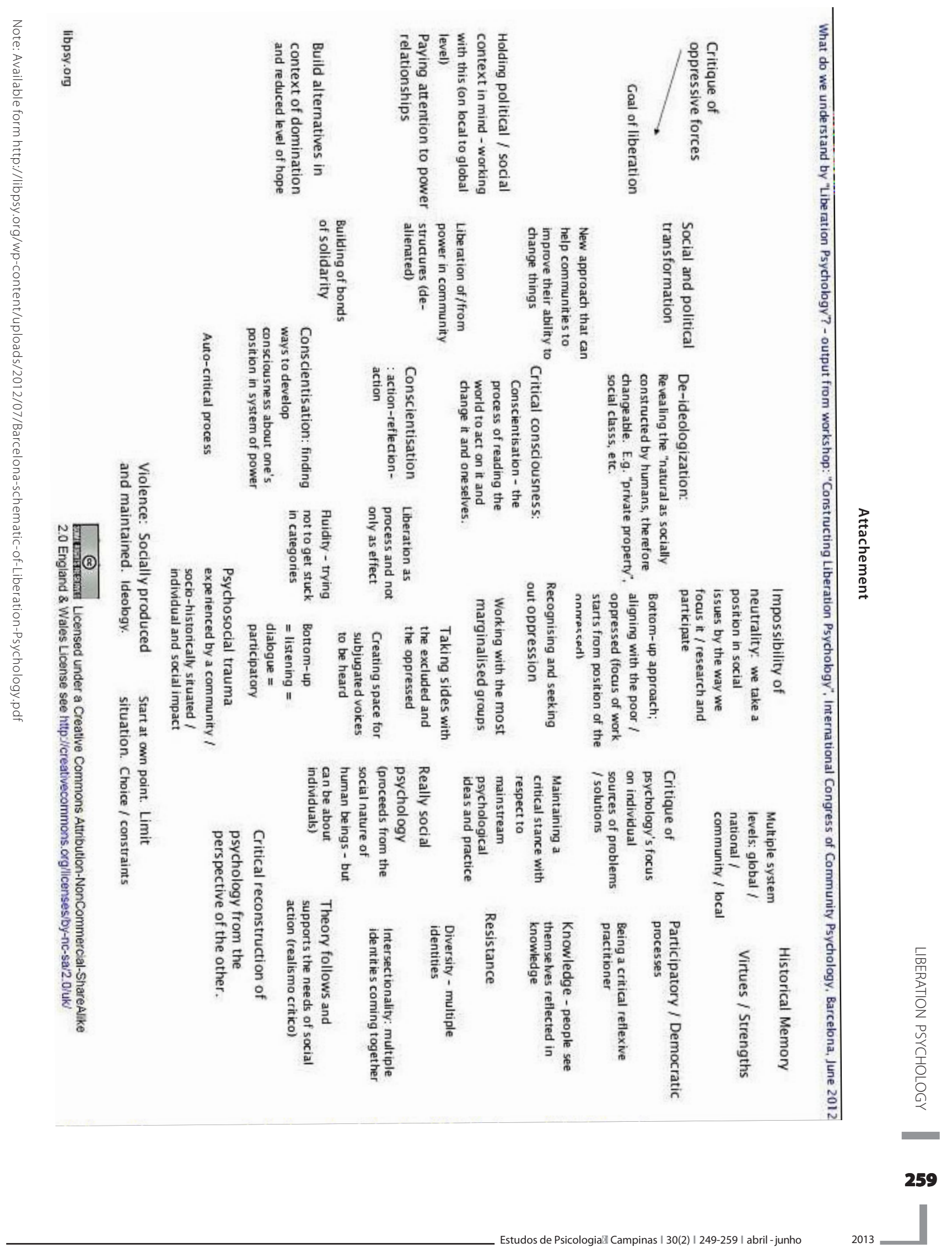


